\title{
Učenje i poučavanje Likovne umjetnosti u srednjoškolskome odgoju i obrazovanju - kritički osvrt i mogućnosti reforme
}

Alviž, Josipa; Nestić, Jasmina

Source / Izvornik: Institucije povijesti umjetnosti : zbornik 4. kongresa hrvatskih povjesničara umjetnosti, 2019, 233 - 237

Conference paper / Rad u zborniku

Publication status / Verzija rada: Published version / Objavljena verzija rada (izdavačev PDF)

https://doi.org/10.31664/z4khpu.31

Permanent link / Trajna poveznica: https://urn.nsk.hr/urn:nbn:hr:254:801564

Rights / Prava: Attribution 4.0 International/Imenovanje 4.0 međunarodna

Download date / Datum preuzimanja: 2023-04-26

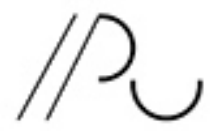

INSIIIUTZZA POVIJEST UMJETNOST
Repository / Repozitorij:

PODEST - Institute of Art History Repository

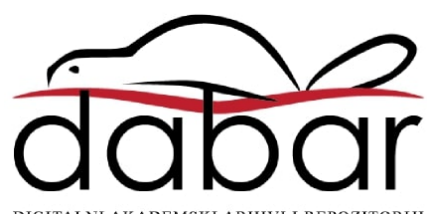




\section{Učenje i poučavanje Likovne umjetnosti u srednjoškolskome odgoju i obrazovanju-kritički osvrt i mogućnosti reforme}

\section{Josipa Alviž Jasmina Nestić}

Josipa Alviž

Odsjek za povijest umjetnosti

Filozofski fakultet

Sveučilište u Zagrebu

jpetrini@ffzg.hr

D https://orcid.org/oooo-oooI-88I5-2743

Jasmina Nestić

Odsjek za povijest umjetnosti

Filozofski fakultet

Sveučilište u Zagrebu

jasmina.nestic@ffzg.hr

https://orcid.org/oooo-oooI-5o63-4456
U dosadašnjim istraživanjima i publikacijama nedovoljno istaknut, a bitan događaj u povijesti hrvatske povijesti umjetnosti, jest uvođenje srednjoškolskoga predmeta Likovna umjetnost u gimnazijske nastavne programe potkraj 50-ih i početkom 6o-ih godina 2o. stoljeća. Predmet je u hrvatske gimnazije uveden prije svega nastojanjima i zalaganjem prof. dr. sc. Milana Preloga, koji je osmislio prvi nastavni plan i program, ${ }^{1}$ jedinstven u europskim okvirima po pristupu likovnom umjetničkom djelu, dok ga je metodički i didaktički vrlo progresivno i dubinski razradila prof. dr. sc. Jadranka Damjanov. ${ }^{2}$ Danas predmet s gotovo šezdesetogodišnjom tradicijom učenja i poučavanja, Likovna umjetnost svojevremeno je trebala strogom argumentacijom opravdati svoje mjesto u hrvatskom srednjoškolskom odgojno-obrazovnom sustavu i izboriti svoj ulazak u gimnazijski nastavni program. Jedna od glavnih zadaća novouvedenog predmeta i razlog za njegovo uvođenje bilo je stajalište da „aktivni kontakt s umjetnošću pridonosi obogaćenju emotivnoga života", ${ }^{3}$ podudarno današnjim odgojno-obrazovnim težnjama koje u žarište interesa stavljaju cjelovit razvoj učenika i važnost cjeloživotnoga obrazovanja pojedinca. U jednom od razgovora prigodom uvođenja predmeta u škole Milan Prelog dao je objašnjenje: „U nastojanju da se stvori jedan cjelovit čovjek, da se stvori unutrašnja ravnoteža čovjeka, izbjegnu pukotine, debalansi između emocionalnog i racionalnog uveden je predmet povijest umjetnosti u škole. Povijest umjetnosti razvija kulturu gledanja, uživljavanja i suosjećanja, i prema tome pridonosi razvoju emotivnog života, te je zato našla svoje mjesto u sistemu nastave." ${ }^{4}$

U središtu je učenja i poučavanja predmeta bio također razvoj osjetilnosti mladih odgojem pažnje i opažaja zasnovanih na dubinskoj analizi i promišljanju likovnih i vizualnih pojava, utemeljeno prije svega na metodičkome radu Jadranke Damjanov, potkrijepljenom znanstvenim istraživanjima iz područja percepcije te uloge kulturnoga obrazovanja mladih. ${ }^{5}$
I Tadašnji nastavni plan i program za predmet Likovna umjetnost dio je jedinstvenoga dokumenta u kojem su objavljeni programi za sve gimnazijske predmete. Vidi: Nastavni plan i program za gimnaziju, u: Prosvjetni vjesnik: službeni organ savjeta za prosvjetu NR Hrvatske, godina XIII, broj 8, 8. ožujka I96o., Zagreb, I6I-20I.

2 Više vidi u: JADRANKA DAMJANOv, Prošlost, sadašnjost i budućnost likovnog obrazovanja u nas, $\mathrm{u}$ : Zbornik I. kongresa hrvatskih povjesničara umjetnosti, (ur.) Milan Pelc, Zagreb, 20oI., 343-346.

3 Upravo ovo stajalište stoji kao naslov objavljenoga razgovora tadašnjega učenika viI. gimnazije u Zagrebu, Vjeke Mahovlića, s Milanom Prelogom. Vidi u: VJEKO MAHOVLIĆ, Aktivni kontakt s umjetnošću pridonosi obogaćenju emotivnog života, u: Umjetnost i mi. Godišnjak povijesti umjetnosti VII. gimnazije, I (ı66./6ı.), bez paginacije.

4 Isto

5 Više vidi u: JADRANKA DAMJANOV, DUBRAVKA JANDA, VELIBOR JERBIĆ, Kulturni sadržaji u obrazovanju: problemi umjetničkog obrazovanja djece i omladine, sv. I i 2, Zagreb, I977.; JADRANKA DAMJANOV, Pogled i slika: šest djela hrvatskoga modernog slikarstva u dostignućima eksperimentalne estetike /Eye Movements and Pictures: Six Paintings of Croatian Modern Art in the Achievements of Experimental Aestethics/, Zagreb, I996. 
Prepoznajući osobitosti metodike povijesti umjetnosti, u svome manifestu povijesti umjetnosti iz ig6o. godine, učenici 4. razreda VII. gimnazije, u kojoj je predavala Jadranka Damjanov, zrelo ističu: „Povijest umjetnosti je odgojna metoda, način, sredstvo, predmet koji nam pruža mogućnosti vlastitog otkrivanja i stvaranja." 6

Postavši najmlađi gimnazijski predmet, Likovna umjetnost imala je važnu ulogu u afirmaciji (struke) povijesti umjetnosti u široj domaćoj javnosti, osobito među mladima, služeći kao jedinstvena platforma ne samo za odgajanje i obrazovanje budućih generacija stručnjaka (povjesničara umjetnosti, kustosa, konzervatora i dr.) već i za oblikovanje buduće kompetentne, aktivne i kritične likovne publike. Školski leksikon posvećen umjetno-

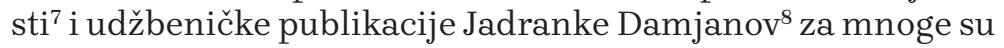
značili prvi susret s povijesnoumjetničkom literaturom, terminologijom i ključnim djelima svjetske i nacionalne povijesti umjetnosti, postavljajući predosnove za dalje razumijevanje, otkrivanje i aktivno sudjelovanje u kulturno-umjetničkim događajima. Gimnazijski udžbenici Jadranke Damjanov, tiskani prvotno početkom 70-ih godina 20. stoljeća, ubrzo su prevedeni i na druge jezike, ${ }^{9}$ a njihova mnoga reizdanja i današnja aktualnost svjedoče o kvalitetnoj metodičkoj postavki toga tada mlada predmeta. Istovremeno je predmet Likovna umjetnost uz Glazbenu umjetnost postao jezgrom umjetničkoga odgojno-obrazovnog područja u hrvatskim gimnazijama i pojedinim strukovnim školama. ${ }^{10}$ Kvaliteta nastave u srednjim školama osigurana je studijskim programom namijenjenim obrazovanju budućih profesora likovne umjetnosti koji se do danas izvodi na Odsjeku za povijest umjetnosti Filozofskoga fakulteta Sveučilišta u Zagrebu, kao i organiziranjem savjetovanja za srednjoškolske nastavnike. ${ }^{11}$ Unutar spomenutoga studija I965. godine uveden je kolegij Metodika, ${ }^{2}$ koji je izvodila upravo Jadranka Damjanov, ujedno dugogodišnja predstojnica Katedre za metodiku nastave povijesti umjetnosti Odsjeka za povijest umjetnosti u Zagrebu. Sve do danas održan je kontinuitet nastavničkoga smjera na spomenutome zagrebačkom fakultetu, a prvotne postavke i sadržaji kolegija Metodika razgranali su se i razradili unutar reformiranoga (bolonjskoga) studija, uvedena 2005 . godine, kroz sustavno organiziranu mrežu kolegija na razini diplomskoga studija povijesti umjetnosti. ${ }^{13}$

Od tih pionirskih dana našega predmeta pa do danas odgojno-obrazovni sustav na svjetskoj je razini prošao niz reformskih promjena potaknutih suvremenim znanstvenim spoznajama iz područja učenja i poučavanja, kao i tehnološkom, prije svega računalnom revolucijom, koja je u cijelosti promijenila način komuniciranja i načine prijenosa znanja omogućavajući primjenu novih odgojno-obrazovnih metoda i oblika rada koji u središte stavljaju učenika, njegovu aktivnost i osobnost. ${ }^{14}$ Tradicionalni odgojno-obrazovni sustav temeljen na nastavnim planovima i programima sa strogo propisanim nastavnim sadržajima i krutom satnicom u većini zapadnih zemalja nastoji se zamijeniti ili je već zamijenjen kurikulumima koje karakterizira veća autonomija škola i njezinih djelatnika u određivanju nastavnih sadržaja i primjeni suvremenih
6 ZORAN BAKIĆ, DUBRAVKA JANDA, JASENKA MIRENIĆ, ANICA ŽUPAN, Što je povijest umjetnosti?, u: Umjetnost i mi. Godišnjak povijesti umjetnosti VII. gimnazije, I (I96o./6I.), bez paginacije.

7 MILAN PRELOG, JADRANKA DAMJANOV, RADOVAN IVANČEVIĆ, Likovne umjetnosti, Zagreb, I963.: JADRANKA DAMJANOV, KSENIJA RADULIĆ, DORA BRAJEVIĆ, VIŠNJA MANASTERIOTTI, HRVOJE LISINSKI, Umjetnost (likovne umjetnosti, muzika, film), Zagreb, I965.

8 JADRANKA DAMJANOV, Likovna umjetnost-Uvod. Udžbenik za prvi razred srednje škole, Zagreb, I97I.;

JADRANKA DAMJANOV, Likovna umjetnost-Povijesni pregled i moderna umjetnost. Udžbenik za II., III. i IV. razred gimnazije, Zagreb, I972.

9 Više vidi u: JOSIPA ALVIŽ, Ad honorem et in memoriam Jadranka Damjanov, u: Kvartal: kronika povijesti umjetnosti u Hrvatskoj, ı/2 (20I6.), 87.

Io Predmet Likovna umjetnost, osim u gimnazijama, izvodi se i u pojedinim strukovnim školama, premda s ponešto drukčijim sadržajem i satnicom. Međutim, u većini strukovnih škola predmet iz područja likovne umjetnosti sadržajno i nazivljem prilagođen je upravo strukovnom profilu škole (primjerice Estetika, Likovna umjetnost u vrtlarstvu, Povijest arhitekture i umjetnosti i dr.).

II Usp. JOSIPA ALVIŽ (bilj. 9), 86.

I2 Vidi u: JADRANKA DAMJANOV (bilj. 2), 344

I3 Metodičke kompetencije budućih magistara edukacije povijesti umjetnosti, odnosno profesora likovne umjetnosti, stječu se pohađanjem i polaganjem sljedećih obaveznih kolegija na diplomskome studiju povijesti umjetnosti Filozofskoga fakulteta u Zagrebu: Metodika nastave povijesti umjetnosti, Nastavna sredstva za izvođenje nastave povijesti umjetnosti, Hospitacije, Praktikum i izvođenje nastave I, Praktikum i izvođenje nastave II te izborni kolegij iz područja metodike struke.

14 Usp. Nacionalni okvirni kurikulum za predškolski odgoj i obrazovanje te opće obvezno i srednjoškolsko obrazovanje (dalje NOK), Ministarstvo znanosti, obrazovanja i športa Republike Hrvatske, 20II., II-30, dostupan na mrežnoj stranici http://mzos.hr/datoteke/Nacionalni_okvirni_kurikulum.pdf(posjećeno ı2. siječnja 20I7.). 
nastavnih metoda i oblika rada te okretanje prema kompetencijskim sustavima i odgojno-obrazovnim ishodima temeljenim na različitim taksonomijama znanja. ${ }^{15}$

U svrhu osuvremenjivanja odgojno-obrazovnog sustava na svim razinama i njegova usklađivanja s europskim i svjetskim okvirima i smjernicama, u Republici Hrvatskoj u posljednjih je jedanaest godina izrađen niz razvojnih i kurikularnih dokumenata, među kojima treba izdvojiti Hrvatski nacionalni obrazouni standard ${ }^{16}$ iz 2005. godine, koji znači reviziju nastavnih planova i programa za osnovnoškolsku razinu obrazovanja, Nacionalni okvirni kurikulum za predškolski odgoj i obrazovanje te opće obvezno i srednjoškolsko obrazovanje iz 20II. godine ${ }^{17}$ te Strategiju obrazovanja, znanosti i tehnologije usvojenu 2014. godine,$^{18}$ čija je realizacija predviđena u okviru Cjelovite kurikularne reforme započete 20I5. godine, a koja je do veljače 2016 . godine iznjedrila prijedloge $5^{2}$ kurikularna dokumenta i tri metodološka priručnika. ${ }^{9}$ Navedeni dokumenti trebali su zamijeniti dosadašnje, mahom zastarjele nastavne planove i programe iz 9o-ih godina 20 . stoljeća. ${ }^{20} \mathrm{Za}$ razmatranu temu bitno je istaknuti i da je u okviru Cjelovite kurikularne reforme izrađen prijedlog Nacionalnoga kurikuluma za nastavni predmet Likouna kultura $i$ Likouna umjetnost. ${ }^{21}$ Tijekom njegove izrade članovi stručne skupine ${ }^{22}$ proveli su i analizu inozemnih kurikuluma, koja je pokazala da je umjetničko odgojno-obrazovno područje, čiji je sastavni dio i predmet Likovna umjetnost, nezaobilazni i integrativni dio svih suvremenih kurikulumskih dokumenata. ${ }^{23}$ Inozemni kurikulumi također su pokazali zaokret prema suvremenim temama bliskim srednjoškolskim učenicima i njihovu svakodnevnom iskustvu i okolini, pa osim likovnoga jezika i stila obuhvaćaju vizualne medije i komunikaciju, dizajn, promišljanje društvene uloge umjetnosti i umjetnika, uloge kulturne baštine u oblikovanju osobnoga identiteta i identiteta zajednice, uloge promatrača kao suoblikovatelja značenja likovnoga djela i slično. ${ }^{24}$

Predmet Likovna umjetnost i u današnje se doba pokazao ponovno spremnim odgovoriti na nove zahtjeve odgoja i obrazovanja koji u središte stavljaju razvoj generičkih kompetencija kod učenika kao što su kritičko mišljenje, kreativnost i inovativnost, aktivno građanstvo, komunikacija, suradnja, digitalna i informacijska pismenost. ${ }^{25}$ Nažalost, stvarna realizacija i praktična primjena svih sastavljenih dokumenata u okviru Cjelovite kurikularne reforme zbog političkih prilika postala je upitna. Odgađanje reforme ili, još gore, negiranje potrebe za reformom, kao jednu od posljedica može imati dodatnu marginalizaciju pojedinih odgojno-obrazovnih područja, kao što je umjetničko, i pripadnih mu predmeta poput Likovne umjetnosti. Stoga se ponovno nalazimo u položaju kada strogim argumentima moramo dokazati i naglasiti njegovu važnost $u$ formiranju srednjoškolskih učenika, prije svega kroz aspekt njihove što kvalitetnije integracije u suvremeno društvo. U svijetu koji karakterizira sveprisutnost i komercijalizacija vizualnog i u kojem „politika vizualnog” zahvaća područje od svakodnevnih popularnih medija preko korporativnih imagineering industrija do obrazovanja i umjetnosti, ${ }^{26}$ vizualno i
I5 Usp. kurikulume navedene u bilj. 23 .

I6 Hruatski nacionalni obrazouni standard, 2005., dostupan na mrežnoj stranici http://www.azoo.hr/ index.php?option=com_content\&id=5867:nastavni-plan-i-program-za-osnovnu-kolu-hnos-i-ostali-programi-\&Itemid=63I (posjećeno I2. siječnja 20I7.). I7 NOK (bilj. 14).

I8 Strategija obrazovanja, znanosti i tehnologije (dalje Strategija), Ministarstvo znanosti, obrazovanja i sporta, Zagreb, 20I4. Strategiju je donio Hrvatski sabor 20I4. godine, a objavljena je u Narodnim novinama, I24 (20I4.). Godine 20I5. tiskana je kao cjeloviti dokument Strategija obrazovanja, znanosti i tehnologije-Nove boje znanja, dostupan na mrežnoj stranici http://novebojeznanja.hr/UserDocsImages/datoteke/ KB_web.pdf (posjećeno I2. ožujka 20I7.).

I9 Svi spomenuti dokumenti dostupni su na mrežnoj stranici http://www.kurikulum.hr/ (posjećeno I2. siječnja 20I7.).

20 Nastavni planovi za sve predmete gimnazijskoga programa dostupni su na mrežnoj stranici https://www. ncvvo.hr/nastavni-planovi-i-programi-za-gimnazije-i-strukovne-skole/ (posjećeno 20. siječnja 20I7.).

2I Nacionalni kurikulum nastavnoga predmeta Likouna kultura i Likovna umjetnost-prijedlog (dalje Prijedlog kurikuluma LU), Zagreb, 2oI6. Dokument je dostupan na mrežnoj stranici http://www.kurikulum.hr/ wp-content/uploads/2or6/o3/Likovna-kultura-iLikovna-umjetnost.pdf (posjećeno 20. siječnja 20I7.)

22 Članovi stručne radne skupine za izradu prijedloga kurikuluma za predmete Likovna kultura i Likovna umjetnost su bili: dr. sc. Josipa Alviž (Filozofski fakultet, Zagreb), mr. sc. Maja Ferček (I. gimnazija, Zagreb), mr. art. Miroslav Huzjak (Učiteljski fakultet, Zagreb), Gordana Košćec Bousfield, prof. (Osnovna škola Poliklinike suvAG, Zagreb), Ida Loher, prof. (Osnovna škola Šestine, Zagreb), Lana Skender, dipl. pov. umj. (Umjetnička akademija, Osijek), mr. art. Sonja Vuk (Akademija likovnih umjetnosti, Zagreb), Elen Zubek, prof. (Gimnazija Velika Gorica, Velika Gorica), dr. sc. Dunja Pivac (Umjetnička akademija, Split); a kritički prijatelji: Vesna Mišljenović, prof. (V. gimnazija, Zagreb) i dr. sc. Jasmina Nestić (Filozofski fakultet, Zagreb).

23 Usp. National Core Curriculum for Upper Secondary Schools 2003: National Core Curriculum for General Upper Secondary Education Intended for Young People, Helsinki, Finnish National Board of Education, 2003.; National Core Curriculum for Basic Education 2004: National Core Curriculum for Basic Education Intended for Pupils Subject to Compulsory Education, Helsinki, Finnish National Board of Education, 2004.; Curriculum for the Compulsory School, Preschool Class and the Recreation Centre, Stockholm, 20II.; Upper Secondary School 20II, Stockholm, 20II.; National Curriculum for Basic Schools, Tallinn, Government of the Republic, 20II.; Subject field: Art subjects, u: National Curriculum for Upper Secondary Schools, Tallinn, Government of the Republic, 20II.; Framework Education Programme for Basic Education, Prag, 2007.; Framework Education Programme for Secondary General Education (Grammar Schools), Prag, 2007.; Art and Design Programmes of Study: Key Stages I and 2, National curriculum in England, 20I3.; Art and Design Programmes of Study: Key Stage 3, National curriculum in England, 20I3.; Arts Education (Elementary School)-Saskatchewan-Curricula. 2. Competency-Based Education-Saskatchewan. Ministry of Education, 20II.; Visual Art Io, 20, 30 Curriculum Requirements, Saskatchewan Education, I996. 
likovno opismenjavanje te razumijevanje vizualne kulture i komunikacije trebalo bi postati neupitnim dijelom obrazovanja svakoga mladog čovjeka. U tom smislu treba se ograditi od etiketiranja predmeta pridjevima elitistički ili ekskluzivistički, koji mu se ponekad stereotipno pripisuju, te uvidjeti njegovu ulogu u razvoju utemeljenih stavova, vrijednosti i kritičkoga mišljenja koji se ostvaruju upravo aktivnim i analitičkim odnosom prema okolini i likovnom stvaralaštvu, što je istaknuto u spomenutom prijedlogu kurikuluma za Likovnu umjetnost (20I6.). ${ }^{27} \mathrm{U}$ istom se dokumentu također ističe: „Emocionalni, asocijativni, intelektualni i stvaralački pristup u poticanju svjesnoga i aktivnoga doživljaja likovnoga/vizualnoga djela i okoline doprinose razvoju percepcije, kreativnosti, komunikacijskih vještina te kritičkomu mišljenju kao trajnim vrijednostima." 28 Pritom se među kompetencijama posebno ističu, s obzirom na virtualno okruženje današnjega doba i njegov utjecaj na poimanje umjetnosti unutar kriterija kvalitete, i one koje su nužne za razvoj kritičkoga stava i selektivnog odnosa spram onih vizualnih poruka koje primamo novim tehnologijama ${ }^{29}$ te razumijevanje slojevitih vizualnih poruka koje su proizvod masovnih medija i tehnologija, a koje snažno utječu na promatračevu percepciju (vizualnu, auditivnu, taktilnu, kinestetičku). ${ }^{30}$

Razmatrani prijedlog kurikuluma krenuo je putem osuvremenjivanja nastavnoga procesa i programa upravo u pogledu njegova oslonca na definiranje kompetencija i odgojno-obrazovnih ishoda koji bi se trebali ostvarivati i zahvaćati sva polja učeničke osobnosti-znanja, sposobnosti i stavovi-a sadržajno se udaljio od kronologije nizanja stilskih razdoblja i usmjerio prema proučavanju likovne problematike (teme, načela, utjecaja i dr.), ostavljajući tako nastavniku autonomiju da nastavni proces učini izvornim, promjenjivim i u svakom trenu suvremenim. Iako se promjene koje je prijedlog donio isprva čine velikima, što i jesu ako promatramo isključivo njegovu strukturu i sadržaj, zasigurno je prepoznatljivo da se njime i dalje želi ostvariti većina onih zadaća predmeta koje se navode $u$ aktualnom Nastaunom planu za gimnazije-Likouna umjetnost (I994.), ${ }^{31}$ kao i već spomenutom Nacionalnom okvirnom kurikulumu (20II.). ${ }^{32}$ Tako se u prijedlogu kurikuluma, među ostalim zadaćama predmeta, ističe i da se Likovna umjetnost „prepoznaje kao jedan od načina komunikacije s okolinom te kao sastavni dio života svakoga čovjeka. Učenici se potiču da vlastitim stvaralaštvom i istraživačkim radom propituju univerzalna i globalna pitanja, da uvažavaju kulturne raznolikosti te prepoznaju njihov utjecaj na likovne umjetnosti radi postizanja razumijevanja i odgovornosti te razvijanja kritičkoga stava prema okolini. Razvija se svijest o raznolikosti kulturnih baština i identiteta kao vrijednostima u suvremenim globalizacijskim procesima." ${ }^{33}$

Od zadnjega izlaganja o statusu predmeta Likovna umjetnost $u$ srednjoškolskome odgojno-obrazovnome sustavu u okviru i. kongresa hrvatskih povjesničara umjetnosti, a održala ga je Jadranka Damjanov, dogodile su se mnoge promjene na svim razinama obrazovanja u Hrvatskoj. Naime, uveden je novi
24 Usp. na primjer National Core Curriculum for General Upper Secondary Education Intended for Young People, Helsinki, Finnish National Board of Education, 2003., $203^{-208 .}$

25 Više vidi u: Okvir nacionalnoga kurikuluma-prijedlog, Zagreb, 20I6., I3-I6, dokument dostupan na mrežnoj stranici http://www.kurikulum.hr/wp-content/uploads/2OI6/o2/ONK-I8.2-POPODNE-2.pdf (posjećeno 20. siječnja 20I7.); NOK (bilj. I4), I7-ı8.; Strategija (bilj. I8), 26.

26 Usp. na primjer W. J. T. MITCHELL, What Do Pictures Want? The Lives and Loves of Images, Chicago, London, 2005.

27 Usp. Prijedlog kurikuluma LU (bilj. 2I), 5 .

28 Isto, 6.

29 Isto.

30 Isto, 86.

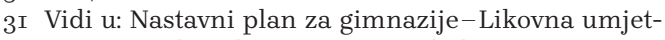
nost, u: Glasnik Ministarstva kulture i prosvjete Republike Hrvatske, I (I994.), 9o. Dokument je dostupan na mrežnoj stranici http://dokumenti.ncvvo.hr/ Nastavni_plan/gimnazije/obvezni/likovni.pdf(posjećeno I7. siječnja 20I7.).

32 Vidi u: NOK (bilj. I4), 208.

33 Prijedlog kurikuluma LU (bilj. 2I), 6. 
model vanjskoga vrednovanja obrazovanja putem polaganja ispita državne mature iz obaveznih i izbornih predmeta koji zahtijevaju specifična znanja i vještine propisane ispitnim katalozima s jasno definiranim odgojno-obrazovnim ishodima za svaki pojedini predmet, pa tako i Likovnu umjetnost. ${ }^{34}$ Bolonjski proces, koji je 2005. godine zaživio u hrvatskome visokoškolskom obrazovanju, rezultirao je reformom sveučilišnih studijskih programa te tako i obrazovanje budućih srednjoškolskih profesora usmjerio stjecanju stručnih kompetencija koje postaju temelj organizacije nastavničkih studija. S druge strane aktualni nastavni plan i program predmeta Likovna umjetnost (I994.), u velikoj mjeri temeljen na prvome programu iz Ig6o. godine, sadržajno i strukturalno nije osuvremenjen gotovo od doba uvođenja toga srednjoškolskog predmeta. S obzirom na sve navedeno važno je da se započeta cjelovita kurikularna reforma nastavi i provede te da se na taj način prate zahtjevi suvremenoga odgoja i obrazovanja, slijedeći dobra iskustva europskih zemalja, vodećih u pogledu organizacije i realizacije kvalitetnih obrazovnih sustava.

Od iznimne je važnosti, dakle, u stručnim krugovima, ali i široj javnosti, i dalje isticati relevantnost i aktualnost predmeta Likovna umjetnost u srednjoškolskom odgojno-obrazovnom sustavu, ukazujući istovremeno na uvijek prisutnu latentnu strepnju za njegovu budućnost, kao i hoće li ga prepoznati vladajuće strukture. U tom pogledu izrazito je velika odgovornost cjelokupne stručne zajednice, osobito predstavnika visokoškolskih, muzejsko-galerijskih i restauratorsko-konzervatorskih ustanova, za očuvanje te važne karike u kulturnome i umjetničkome obrazovanju mladih. Znanja stečena zahvaljujući predmetu Likovna umjetnost prva su stepenica daljega razvoja širokoga spektra raznovrsnih kulturnih djelatnosti. Nestanak toga temelja sasvim bi sigurno utjecao na kvalitetu visokoškolskoga obrazovanja iz povezanih disciplina, doveo do još veće degradacije kulturnoga obrazovanja mladih i porasta vizualne nepismenosti te uzrokovao bitno smanjenje kompetentne kulturne publike i budućih stručnjaka.

\section{(a) (1)}

Učenje i poučavanje Likovne umjetnosti u srednjoškolskome odgoju i

obrazovanju-kritički osvrt i mogućnosti reforme/Josipa Alviž / Jasmina

Nestić / CC BY / 4.0

DOI: https://doi.org/Io.3I664/z4khpu.3I
34 Vidi: Ispitni katalog za držaunu maturu u školskoj godini 20I6./20I7. Likouna umjetnost, Nacionalni centar za vanjsko vrednovanje obrazovanja, dostupan na mrežnoj stranici https:/www.ncvvo.hr/wp-content/ uploads/20I6/og/LIU_IK_I7.pdf(posjećeno I7. siječnja 2017.). 